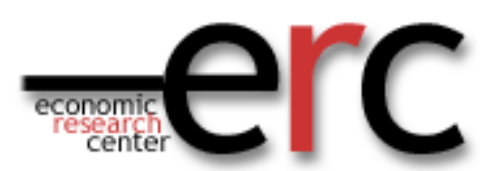

ERC Working Papers in Economics 13/04

March/ 2013

\title{
Private Tutoring and the Question of Equitable Opportunities in Turkey
}

\author{
Aysit Tansel \\ Department of Economics \\ Middle East Technical University \\ 06800 Ankara, Turkey \\ E-mail: atansel@metu.edu.tr \\ Telephone: 90.312.210 2057 \\ Fax : 90.312.210 7964 \\ and \\ Institute for the Study of labor (IZA) Bonn, Germany \\ and \\ Economic Research Forum (ERF) Cairo, Egypt
}




\title{
Private Tutoring and the Question of Equitable Opportunities in Turkey*
}

\author{
Aysit Tansel \\ Department of Economics \\ Middle East Technical University \\ 06800 Ankara, Turkey \\ E-mail: atansel@metu.edu.tr \\ Telephone: 90.312.210 2057 \\ Fax : 90.312.210 7964 \\ and \\ Institute for the Study of labor (IZA) Bonn, Germany \\ and \\ Economic Research Forum (ERF) Cairo, Egypt
}

March 14, 2013

\begin{abstract}
This paper focuses on the implications of private tutoring in Turkey for questions of equity regarding the provision of public education, based on an analysis of previously published research. The nature of the private tutoring and its relation to the two national selection examinations in Turkey are also discussed.
\end{abstract}

\section{Key Words:}

Turkey; Private tutoring; Educational equity; National Selection Examinations.

JEL Codes: I21,I24, I25

* I gratefully acknowledge the comments and suggestions of Giray Berberoğlu, Mark Bray, André Elias Mazawi and Ronald Sultana. Any errors are my own. 


\section{Introduction}

Private tutoring is one of the most important issues in the countries where there is a large demand for the higher education but the access to higher education is limited by entrance examinations. Under those circumstances, the highly competitive University Entrance Examination (UEE) becomes the only target among students. The educational system basically focuses on competition. As a result, the quality of teaching and learning practices are impoverished. The major objective in high stake examinations becomes selection. The selection process ranks the students with respect to their test scores in order to be able to discriminate among them. However, a discriminatory approach to education is not desirable. The aim should be to harmonize individual differences with respect to knowledge and skills acquired (Berberoğlu and Tansel, 2012) Unfortunately, student selection for university programs hampers the educational rights of individuals (Gök, 2010). Over this backdrop, both the parents and the students are overly concerned with the entrance examinations. In relation to that, private tutoring plays an important role in the students' preparation for the entrance examinations.

In the schools the common examination type is the essay examination whereas the UEEs are based on multiple-choice questions. One function of private tutoring is to prepare students in techniques of answering multiple choice questions. Therefore, private tutoring could be thought of concentrating on mechanical teaching-learning practices. Given the importance placed on private tutoring, the schools become credential-granting institutions. Moreover, not all the students have equal access to private tutoring since it is related to parents' income and wealth. Therefore, private tutoring exacerbates socio-economic inequalities. Students from wealthy backgrounds could attend the most prestigious private tutoring institutions and be selected via the entrance examinations. Students from less wealthy backgrounds may not be able to afford any private tutoring at all.

This paper deals with equity implications of private tutoring in Turkey. The intersection between private tutoring and equity issues are discussed in the first part of the paper. The second part of the paper explains the nature of private tutoring and the two national examinations Turkey. The relationship between the national examinations and the development of the private tutoring is elaborated on, before concluding with a set of observations. 


\section{Private tutoring and equity in Turkey}

Inequities in the provision of educational services are evident when comparing private (household) and public (government) expenditure on education. The total private educational expenditure is higher in Turkey than in most countries, estimated to stand at $2.5 \%$ of the GDP in 2002 (TURKSTAT, 2011). The OECD average of private educational expenditure as percent of GDP was 0.9 percent in 2008 (OECD, 2011). Private educational expenditure includes expenses on private tutoring as well as tuition for private schools. In contradistinction, the GDP share of public educational expenditure in Turkey was 4.76 percent in 2002 (TURKSTAT, 2011) which is lower than the OECD average of 5.0 percent in 2008 (OECD, 2011). The high private expenditure and the low public expenditure in Turkey are indicators of socioeconomic inequity in the provision of educational services. In 20012002 academic year parents spent more than 1.4 percent of Turkey's GDP on private tutoring (Tansel and Bircan, 2006). In 2005, per student expenditure was equivalent to US\$ 5,322 on the preparation for the UEE through private tutoring (TED, 2005). According to the Private Tutoring Association, Öz-De-Bir (2012) during the 2010-2011 academic year, the average annual private tutoring fee ranged from about US $\$ 1,300$ to US $\$ 6,500$ depending on the number of hours of instruction and the number of students in the class. This fee could be contrasted with the legal minimum wage in Turkey. The annual net minimum wage of a worker (16 years of age and over) in Turkey in 2012 was just under US\$ 5,000 (Turkish Accountants Association, 2012). Therefore, a worker earning the minimum wage would not be able to afford buy private tutoring for her/his children.

The Education Initiative Report (ERG, 2011) observes that education policies should be developed and applied in a way that does not discriminate against geographical regions, gender and socio-economic groups. From this perspective, considering the more established socio-economic level of students receiving private tutoring raises questions about inequity in the Turkish educational system. For many, private tutoring is a response to poor quality public 
education system. An increase in public education expenditure to improve quality of public schools may reduce the demand for private tutoring or it may not. ${ }^{1}$

The inequity underpinning private tutoring raises grave concern for government and educators. The 1980 military government in Turkey banned Private Tutoring Centers (PTCs) because of their concern for equity consideration. In 1983 a law was passed which required the closure of the PTCs within one year of 1984. The ban was lifted before it took effect because of the lobbying activities of the Private Tutoring Centers. There were only 174 PTCs at that time across the country. This event was a turning point in the history of the PTCs in Turkey $^{2}$. It led to the establishment of the first association of the PTCs called Öz-De-Bir in $1985^{3}$. Today, Öz-De-Bir is the oldest and the largest of the several other PTC associations in the country. Tansel and Bircan (2008) have observed that private tutoring exacerbates social stratification and inequalities in Turkish society. Household income and parental education levels play important roles in determining access to private tutoring (Tansel and Bircan, 2006). Parents with high incomes can buy better quality and greater intensity of private tutoring while poor parents cannot afford the same. Parents with high levels of education also afford a better quality and greater amounts of private tutoring compared to parents with low levels of education. As a result, those students whose parents can afford private tutoring have an advantage over those who cannot in getting into the elite, high quality high schools and universities and obtaining higher incomes and prestigious positions in the labor market and the society. Wealthy parents view private tutoring as securing a competitive advantage for their children. In contrast, Öz-De-Bir officials have argued that PTCs provide services for middle- and low-income families at affordable prices compared to a private one to one teacher. PTCs are required to register five percent of the students from lower income families free of charge. Öz-De-Bir stated that this figure is more like 10 percent for its members (ÖzDe-Bir, 2012). Clearly, the controversies over private tutoring in Turkey are deeply enmeshed with contending social class dynamics.

\footnotetext{
${ }^{1}$ Notwithstanding, in Hong Kong, Singapore and Korea, despite excellent public schools, still have much private tutoring, which is driven by social competition.

${ }^{2}$ The history of the private tutoring centers in Turkey goes back to a law dated 1965 which legalized them.

${ }^{3}$ Öz-De-Bir stands for "Özel Dersaneler Birligi”" which literally means "Association of the Private Tutoring Centers".
} 
Notwithstanding, social class represents only one axis of demarcation with regard to the nexus between private tutoring and educational inequities. There are other axes of demarcation along which these inequities and inequalities operate. These include gender, region, rural/urban background, type of high school and before 2010 the streams of study in the high school. Girls have only a small advantage over boys in terms of attending private tutoring (Tansel and Bircan 2008). A comparison of the geographic distribution of the PTCs and general high schools can be found in Tansel and Bircan (2008). The east and the south-east regions of Turkey have fewer PTCs compared to other regions of the country and PTCs operate mostly in urban areas. Moreover, students from the Black Sea region, east and southeast regions are somewhat less successful in UEEs compared to other Turkish regions although according to the findings of Berberoğlu and Kalender (2005) these regional differences are not significant in the 1999-2002 UEEs and the 2003 Programme for International Student Assessment (PISA) examination results in Turkey .

Differences in school quality represent additional facets of the larger question of equity. Parents send their children to PTCs, thus exacerbating socio-economic effects on scholastic achievement. A vicious circle thus feeds on inequalities among schools, raising the demand for private tutoring. There are large differences in school quality in Turkey. In particular, high schools differ in quality by the type of high school as indicated by the performance of the students in the national and international tests. According to the results of the UEE and PISA there is a wide variation in the performance of the students from various high schools in Turkey. This reflects the quality of high schools. The evidence indicates that the students from science high schools, Anatolian high schools and private high schools have a very high chance of being successful in the UEE. Their performance in PISA is much above the international average. Compared to this the students from general high schools who are less successful in the UEE and their performance in PISA is below the international average. These issues are discussed in more detail in the next section. Several studies indicate that the socio-economic and family background are important determinants of the performance in the examinations (Günçer and Köse, 1993; Dinçer and Uysal, 2010). The results show that the students from Science high schools, Anatolian high schools and the private high schools come from more affluent family backgrounds. This is confirmed by the following quotation: “... approximately two-thirds of the students in science high schools and one-half of the students in Anatolian high schools belong to the richest 20 percent of the households where at least one 15-year-old lives" (World Bank, 2011). Students from these schools go on to be 
successful in the UEE, and eventually in the labor market and the society. The number of elite, high quality high schools are only a few compared to the number of general high schools. Therefore, they admit students with an entrance examination for which it is common to prepare by taking private tutoring.

Since the 2010-2011 academic year the high school curriculum has changed to include a group of must courses which must be taken by all students and elective courses chosen by the students based on their interest and future career plans about the university program that they would like to apply. The first year of high school includes common must courses only. The following years include common, must courses as well as elective courses. This makes the system more flexible. However, before the 2010-2011 academic year there were four major general high school streams of study: Mathematics-Natural Sciences, Turkish-Mathematics, Turkish-Social Sciences and Foreign Languages. Students chose one of these streams during their high school years, based on their interest, their Grade Point Average (GPA) in the courses of the different fields of study and their future plans about the university program that they would like to apply. The students who are at the end of the $12^{\text {th }}$ grade in high school or high school graduates can take the UEE. Mathematics-Natural sciences and TurkishMathematics were the most popular streams among the students because of the belief that the students from these streams have a better chance of success at the UEE. Students in the Mathematics-Natural Sciences and the Turkish-Mathematics streams receive a more intensive mathematics curriculum compared to students in the Social Sciences and Foreign Language streams. There is no direct information about the distribution of students across the various streams. However, among the high school seniors and graduates who applied to the UEE in 2008, 33.3 percent had Mathematics-Natural Sciences background and 31.2 percent had Turkish-Mathematics background. Those who had Social Sciences background were only 13.3 percent. Those who majored in the Foreign Language streams accounted the 23.1 percent of the applicants to the UEE (Berberoğlu and Tansel, 2012).

\section{Private tutoring and national examinations}

In this paper we argue that the development of private tutoring is connected with the national examination system in Turkey. There are two major national examinations in Turkey. The first is the national examination taken at the end of the eighth school grade of compulsory schooling. This examination selects the students who will proceed to elite and high quality 
schools such as science high schools, Anatolian high schools and private high schools. Students can prepare for this examination in various ways, including by taking private tutoring. Entering an elite high school increases a student's chances of subsequently entering an elite university and obtaining a good position in the labor market and the society. The second major national examination is the UEE. It is taken by high school students at the end of their senior years (twelfth grade) and by high school graduates. It is a highly competitive examination that determines whether a student can enter a prestigious university and whether that student would be successful in the labor market. Students often start preparing for this examination during the first year of high school by having private tutoring. Preparations intensify during the last year of high school.

The UEE system is centralized since 1974 and conducted by the Student Selection and Placement Center. This is the body that prepares and conducts the examinations for selecting and placing students into Turkish higher education programs. There was a single-stage examination system until 1981 whereby students took the examination in one sitting at the same date and time all over the country. In 1981 two-stage examination was adopted which were given with about two months interval in between. In 1987 there was a reduction in the number of the subjects that must be answered in the examination. In 1999 a single-stage examination was re-instituted. Currently there is two- stage examination again.

According to the current information provided by the Student Selection and Placement Center (2012), the first stage examination (called YGS) will be given in April, 2012 and the second stage examination (Called LYS) will be given in June, 2012. YGS is designed to assess the students' ability to think through and use the basic concepts in the high school curriculum common to all students. The subjects include Turkish language, Social Sciences (History, Geography and Philosophy), Basic Mathematics and Naturel Sciences (Physics, Chemistry and Biology). Tests include multiple choice questions with five alternatives. YGS is taken in a single sitting that lasts for 160 minutes. Weighted scores are computed. Those who score less than 140 will not be eligible to participate in any one of the higher education programs. Those who score 140-179 will be eligible to be placed in one of the two-year vocational associate degree programs or the two-year or four-year Open Education Programs. The Open Education Program is based on distance education. It is one of the largest distance education programs in the world. During the academic year of 2010-2011 there was a total of 1.714 
million students registered in two-year or four-year distance education programs (Student Selection and Placement Center. 2012).

Those who score 180 or more in at least one of the tests of YGS will be eligible to further participate in the LYS. LYS is given in June, 2012 on four separate days, in four separate fields. These fields are Mathematics-Geometry, Naturel Sciences, Literature-Geography, Social Sciences and Foreign Languages. The candidates choose among these fields depending on their streams of study in high school and on the requirements of the university programs they would like to enter. Weighted scores are computed. Those who score a 180 or more in the LYS will be eligible for placement into a four-year university program. There is a complex system of computing the weighted scores. This system takes into account the graduation grade in the high school. This depends on the high school graduated, graduation year and the graduation grade. The weight changes according to the distribution of the graduation grades in the high school and the place of the student in this distribution. Those students who graduate as the top student of their high school and those who receive prizes in national or international competitions can receive additional points in the weighting scheme and/or not take the UEE (Student Selection and Placement Center, 2012).

The increasing number of high school graduates, coupled with quotas imposed on university admissions makes UEE highly competitive too. In 1980, the number of applicants to the UEE was 466,963 and 41,574 of them were selected and placed in a four year university program( there were no two-year programs at that time). Thus, the proportion of those who were placed was only 8.9 percent. Both the number of applicants to the UEE and the proportion of those who are placed in a university program have increased over time along with the increase in the number of high school graduates. In 2008, only about a third of all $1,574,928$ applicants were selected and placed in the two or four-year higher education programs. In 2010, there were 1,587,866 applicants to the UEE. The 874,306 of the applicants were selected and placed into a two or four year higher education program. Thus, 55.1 percent of the applicants were placed in 2010 (Student Selection and Placement Center, 2012). This increase in the proportion of those who are placed in a university program is due to the recent increase in the quotas of the universities and the establishment of the new both public and private universities increasing their number. 
As remarked earlier the main post-high school, higher education programs in Turkey include two-year programs of associate degree, four-year programs of bachelor's degree (six years in case of medical schools) and other programs. There are also masters and Ph.D. degree programs. At the high school level, first of all we differentiate between general high schools and the vocational high schools. There are a variety of different types of general high schools such as science high schools, Anatolian high schools, private high schools and general (public) high schools. These schools differ widely in terms of quality of education. This was identified as one of the sources of inequity in the discussions of the previous section. The performance shown by the graduates of these high schools at the UEE also varies widely. The admission rate to a four year university program which shows the proportion of the applicants who are placed into a four year program is as follows. For the applicants from the social sciences high schools the admission rate was the highest with 82.17 percent. The next highest rate was for the private science high school applicants with 69.43 percent. The admission rate was 63.41 percent for the public science high school applicants, 60.45 percent for the Anatolian high school applicants and 59.56 percent for the foreign language private high school applicants. In contrast, the admission rate for the general public high schools which comprise the majority of the general high schools, was only 22.78 percent (Student Selection and Placement Center, 2012). These statistics indicate that the applicants who are most successful in the UEE come from the science high schools, Anatolian high schools or the private high schools.

Similar conclusions were reached by the authors who investigated the success of the students from various types of high schools in Turkey. Köse (1999) investigated the success of the students in the 1995 UEE according to the types of the high school that the students attended. He found that the students from science high schools, Anatolian high schools and the private high schools have a higher chance of placement at a university program compared to students from a general public high school or vocational high school. He attributes this to the selection examinations that the former schools administer in admitting students. Thus these students representing a select group. Berberoğlu and Kalender (2005) examined the scores of the Turkish students in the 1999-2002 UEE and the 2003 PISA. They found that the differences between school types are larger and more important than the differences between the regions across Turkey. The students from science high schools, Anatolian high schools and the private high schools performed above average in the UEE and the PISA and while the students from general and vocational high schools performed below average. In particular the 
performance of the students from science high schools in PISA was very high. Their standard scores were two standard deviations above the international average (Berberoğlu and Kalender, 2005). Günçer and Köse (1993) examined the effects of family background, high school type and the PTCs on the academic achievement of the Turkish high school seniors. They found that the family background is more important than the other factors in explaining academic achievement. Dinçer and Uysal (2010) also reached the similar conclusion.

Those who could not succeed in the UEE either prepare for the UEE again for the following year (mostly by attending PTCs), or look for a job. Those who do not obtain a placement into a university program, in general, represent a population that does not have the necessary labor market skills. This is because the general high school curriculum (as opposed to vocational high schools) concentrates on academic preparations rather than labor market skills. Access to a prestigious university program is a major concern of parents and students.

Ekici (2005) investigated the examination related attitudes of a group of high school students from various schools in Ankara. He found that students who attend PTCs developed positive attitudes towards UEE compared to the students who did not attend PTCs. This finding did not differ by gender or by the type of high school attended. These results indicate that the students attending PTCs develop self-confidence about taking the UEE.

Within this larger context, despite 12 years of formal schooling, parents and students overplay the function of private tutoring, considering it as the main solution to performing well on the entrance examination to elite high schools and the UEE, and gaining access to a university. As a result, Kuban (2011) observes that schools and teachers lose their power and prestige in society. More value is given to PTCs (TED, 2005). PTCs emphasize mainly exercises intended for memorizing and remembering sample question formats and their answers (Gök, 2010). Finally, private tutoring exacerbates social inequalities by selecting the most successful students, training them for the entrance examinations, while consolidating their own prestige and standing.

The preparation process for the two national examinations disrupts the formal schooling attendance especially during the second semester of the senior years of primary school and the high school. Students attend PTCs rather than classes in mainstream schools. They provide 
expensive, false medical reports of sickness to account for their absence from their mainstream classes. Further, national examinations do not cover all of high school subjects. Subjects such as sports, arts, music and foreign languages are not covered in the UEE and therefore not given importance in high school teaching. In particular, most high school graduates lack foreign language skills except those graduating from the foreign languages stream. Moreover, the competitive nature of the examinations adversely affect the social relations among students. This attitude hinders the development of mutual trust and cooperation among youngsters.

With the increase in the number of primary and high school students in the educational system the number of PTCs has also increased. From 1997 to 2006 the number of PTCs increased by $148 \%$, while the number of students receiving private tutoring increased by $198 \%$ (TED, 2005). During the 2010-2011 academic year, there were 1.235 million primary and high school students receiving private tutoring. There were 4,099 PTCs and 50,209 private tutoring teachers in Turkey (Ministry of National Education, 2011). In comparison, during the 2010-2011 academic year, the total number of primary school students was 10.981 million. The total number of general and vocational high school students was 4.749 million during the same year (Ministry of National Education, 2011). This gives a total of 15.730 million potential PTC students in the primary school and high school levels. Perhaps the number of students in their senior years at the primary school and at the high schools could give a better idea about the potential PTC applications because the preparations for the national selection examinations intensify during the senior years of these schools. During the 2010-2011 academic year the number of students in the eighth grade (last year) of the primary schools was 1.367 million. The number of students in the twelfth grade (last year of the high schools) was 1.552 million during the same year (Ministry of National Education, 2011). This gives a total of 2.919 million senior students in the primary and high schools as potential PTC students. A survey conducted by TED (2005) compared the quality of teaching in PTCs and mainstream schools. It revealed that $44 \%$ of the high school seniors, $65 \%$ of the high school graduates, and $34 \%$ of the university students believed that the quality of teaching was better at the PTCs compared to mainstream schools.

Using and analyzing data supplied by the Student Selection and Placement Center, Berberoğlu and Tansel (2012) found the proportion of the applicants to the 2008 UEE who received private tutoring. They reported that the $85 \%$ of the applicants with the Mathematics-Natural 
Sciences high school stream received private tutoring. This was true for $71 \%$ of the applicants with the Turkish-Mathematics stream and 53\% of the applicants with Social Sciences stream. Thus, students from the more popular high school streams of MathematicsNatural Sciences and Turkish- Mathematics were more likely to receive private tutoring. This may be due to the more rigorous mathematics curriculum they receive in these streams. Berberoğlu and Tansel also compared students who received private tutoring to those who did not receive any private tutoring in terms of their parental background characteristics. They found that students who did not receive private tutoring have modest socio-economic backgrounds. In contradistinction, students who received private tutoring have more affluent parents. They also tend to have higher interest in and perceptions of academic success than students who do not receive any private tutoring (Berberoğlu and Tansel, 2012).

Baştürk and Doğan (2010) investigated the views of mathematics teachers in Istanbul on PTCs. The teachers explained that the students go to PTCs in order to learn about the techniques of taking multiple choice tests and gain experience in taking such tests. The teachers expressed concern about PTCs being a large economic sector with profit motives. They also expressed concern that students' eventual success in the UEE is attributed solely to their attendance to the PTCs but their teaching at the mainstream schools are not given any credit.

According to Morgil et al. (2001) teachers think that attendance to the PTCs have a negative effect on the students' attitudes in their classes. Some students do not pay attention in class thinking that they will learn the topic at the PTC. Other students who already learned the topic at the PTC can fall into conflict with their teacher. Teachers also think that students get divided as those who are attending PTCs and as those who are not attending PTCs. This division increases importance of the PTCs and drops the mainstream schools to a secondary position in importance. Teachers also feel the internal pressure of the UEE and therefore, concentrate more on the topics that are likely to be on the UEE (Morgil et al., 2001). Students attend the PTCs in order to learn test taking techniques, to prepare for the national examinations and to overcome the examination anxiety by taking a lot of practice tests.

Some students and parents think that it is a must to attend PTCs in order to succeed in national selection examinations. Some teachers thought that practicing test taking techniques is an important advantage of attending the PTCs however the important disadvantage is that 
the students do not learn to express themselves (Morgil et al., 2001). The faculty at the universities note that the incoming students lack explanation and interpretation skills because they have concentrated on answering multiple choice questions throughout their primary and high school careers at the PTCs (Ortaş, 2006). Morgil et al. (2001) investigated the importance of the pilot examinations that are given at the PTCs by Öz-De-Bir. As remarked earlier such pilot examinations are given throughout Turkey at the same date and time. Morgil et al. found that there is a positive highly significant relationship between the scores of the students at the pilot examinations and the actual UEE. The results also indicated that chances of success at the UEE increased by the attendance at the PTCs. Further, these results differed by the various regions of the Turkey.

\section{Private Tutoring Centers and Their Association Öz-De-Bir}

The UEE system and private tutoring venues are connected in many ways, the most important of which were discussed by Tansel and Bircan $(2006,2008)$. There are three different forms of private tutoring in Turkey. The first is one-to-one individualized teaching delivered by either accomplished students of prestigious universities or retired or currently active teachers. It is the most expensive form of tutoring. Tutors often guarantee the success of their students, charging high fees. The second form of private tutoring takes place on school premises by volunteer teachers. This is organized for a nominal fee, outside of formal classroom hours for students who need help with their classroom work. School boards organize this form of private tutoring with the permission of the Turkish Ministry of National Education. It is more common in primary school than in high school. The third and most prevalent form of private tutoring is provided by PTCs, known as "dersane" in Turkish". Licensed by the Ministry of National Education, they resemble schools, with professional teachers working for profit. Teachers who work in public schools are prohibited from teaching at PTCs unlike in Taiwan where teachers in public schools are also allowed to work in the PTCs (Morgil et al., 2001). PTCs provide courses that supplement mainstream school subjects. However, their main activity centers on preparing students for the national examination for entry to elite high schools and for the national examination for entry to universities. They also provide counseling and guidance on the choice of universities, study

\footnotetext{
${ }^{4}$ This word literally means "house of courses" in Turkish.
} 
fields and future career selection. PTCs administer initial placement tests to their applicants. The students who do best on these tests are registered free of charge. The eventual success of these students in the high school examination or in the UEE advertises the effectiveness of their PTC teaching.

As mentioned earlier Öz-De-Bir is the largest and the oldest association of the PTCs. Öz-DeBir represents its members in the official meetings and in the public. One of the topics of discussion with the government officials is the reduction in the tax obligations of its members to the same level paid by the private schools. As Öz-De-Bir views it, there are two important functions of the PTCs. The first is to support the students in the subjects that they are deficient. The second is to prepare them for the national selection examinations (Öz-De-Bir, 2012). A typical PTC provides 500-700 hours of instruction annually (Vatan, 2009).

This instruction takes place after the school hours during the weekdays and also during the weekends. In 2009 there was a 25-30 percent increase in the number of students registered with the PTCs. This was mostly due to the registry of the vocational high school students who were allowed to sit in the UEE during that year (Cumhuriyet, 2009).

Öz-De-Bir has been administering pilot examinations before the national selection examinations take place every year since 1985 . The pilot examinations are given at the same date and time across the country. Öz-De-Bir prepares the examinations and announces their results. The pilot examinations enable the students to become familiar with the national examinations system, cope with their examination anxiety, learn their deficient areas and ameliorate them.

Öz-De-Bir conducts studies to develop a standard of teaching and increase the quality of education of its member PTCs. It follows the developments abroad and informs its members. Öz-De-Bir has organized trips to countries such as UK, Japan and Greece in order to visit the private tutoring institutions in these countries. Öz-De-Bir publishes various books and test banks which help to prepare for the national examinations. It also publishes a regular newsletter for its members with up to date news and announcements (Öz-De-Bir, 2012). ÖzDe-Bir functions as an educational NGO (Non-Governmental Organization). It organizes conferences and workshops for the public on social, cultural and educational issues. The year 
of 2010 was the $25^{\text {th }}$ anniversary of Öz-De-Bir. In order to celebrate this it organized conferences across the country for parents, students and counseling teachers on important topics such as "Success in Examinations and in Life" and "Psychological Support of Children" (Öz-De-Bir, 2012).

In April 2010, it was reported in the news-papers that the prime minister talked about closing down the PTCs. Öz-De-Bir responded to this by saying that the PTCs are being made scape goats for the educational problems of the country and argued that the PTCs complement the education given at the mainstream schools (Öz-De-Bir, 2012). On the other hand, the strategic plan of the Ministry of Education for the period 2010-2014, discussed the possibility of transforming 70 percent of the suitable PTCs to private high schools or primary schools by 2014 (Ministry of Education, 2009). Öz-De-Bir sees the future of PTCs in providing lifelong learning (Öz-De-Bir, 2012).In an interview on March 25, 2012 with the news reporters, the prime minister said that the UEE (Yüksek öğretime Geciş Sinavi, YGS) will be eliminated and the PTCs will be transformed to private high schools (Hürriyet, 2012).

\section{Conclusions}

There are several implications of the present study. First of all, private tutoring is more common among children of families with higher income and wealth and with higher education levels. Second, the students' socio-economic and family background represent important determinants of students' performance in the entrance examination to elite and high quality high schools and in the university entrance examination. Third, there are significant differences in school quality especially between different types of high schools. Differences in examination performance are also related to the type of high schools besides the socioeconomic and family background of the students. There are very few elite, high schools of high quality. Access to these schools such as science high schools, Anatolian high schools and private high schools depend on the entrance examination taken at the end of eighth grade. For the purposes of preparation for these examinations some students attend private tutoring centers "as early as 10 years old" (World Bank, 2011). However, access to the private tutoring depends on the income and wealth of the parents. Thus private tutoring exacerbates social stratification and inequities in the Turkish society. 
In conclusion, the social class, the family background, quality difference between high school types, organizational distinctions between study streams in high school and rural/urban locations are all implicated in the reproduction of social inequities between various groups in Turkish society, of which private tutoring is but one manifestation.

A major recommendation is that policy makers in Turkey must rethink the opportunity structure currently operating within public education, in ways that offers equitable and sustainable success chances to all social groups. The needed support systems must be thought through as well.

\section{References}

Baştürk, S. and S. Doğan (2010) Lise Öğretmenlerinin Özel Dersaneler Hakkındaki Görüşlerinin İncelenmesi ( Investigating High School Teachers' Views on Cram Schools) Uluslarasi Insan Bilimleri Dergisi (International Journal of Human Sciences), Vol.7(2), pp. 135-157.

Berberoğlu, G. and I. Kalender (2005) Öğrenci Başarısının Yıllara, Okul Türlerine, Bölgelere Göre Incelenmesi: ÖSS ve PISA Analizi (Analysis of Student Achievement by Year, School Type and Regions: ÖSS and PISA Analysis), Eğitim Bilimleri ve Uygulama (Educational Sciences and Practice), Vol. 4(7), pp. 21-35.

Berberoğlu, G. and A. Tansel (2012) Private Tutoring and Academic Performance: Evidence from Turkey, Mimeo. Ankara, Turkey: Department of Economics and Department of Secondary School Mathematics and Science Education, Middle East Technical University.

Dinçer, M, A, and G. Uysal (2010) Determinants of Student Achievement in Turkey, Istanbul, Turkey: Bahceşehir University Center for Economic and Social Research (BETAM) Working Paper.

Cumhuriyet Daily News-Paper (2009) Dersanelere Akin (Flooding into Private Tutoring Centers), 29 September 2009.

Eğitim Reformu Girişimi (ERG) (2011) Millet Vekillerine Mektup (A letter to the Members of the Parliament). İstanbul, Turkey.

Ekici, G. (2005) An Investigation of the Attitudes of Students' Toward the Student Selection Examination Through a Number of Variables, Eğitim Yönetimi (Educational Administration) Vol. 28, pp. 82-90.

Gök, F. (2010) Marketing hope: Private institutions preparing students for the university entrance examination in Turkey, In S. Karin Amos (ed.) International Educational Governance, International Perspectives on Education and Society, Vol. 12, pp. 123-134. 
Günçer, B. and M. R. Köse (1993) Effects of Family and School on Turkish Students' Academic Performance, Education and Society, Vol. 10, pp. 105-118.

Hürriyet Daily News Paper (2012) YGS ve Dersaneler Kalkiyor (University Entrance Examination and Private Tutoring Centers will be Eliminated), 25 Mart, 2012.

Köse, M. R. (1999) Üniversiteye Giriş ve Liselerimiz (University Entrance and Our High Schools), Hacettepe Üniversitesi Eğitim Fakültesi Dergisi (The Journal of Hacettepe University School of Education), Vol. 15, pp. 51-60.

Kuban, D. (2011) Dersane mi Istersiniz, Öğretim mi? ( Would You Like Private Tutoring or Teaching?) Cumhuriyet Bilim Teknik, Vol. 1282/2, October 14, 2011.

Ministry of National Education (2009) Milli Eğitim Bakanliği Stratejik Planı 2010-2014 ( Ministry of National Education Strategic Plan 2010-2014), Ankara, Turkey: MEB Strateji Geliştirme Baskanliği.

Ministry of National Education (2011) National Education Statistics, Formal Education, 2010-2011, Ankara, Turkey: Ministry of National Education.

Morgil, I., A. Yılmaz and O. Geban (2001) Özel Dersanelerin Üniversiteye Girişte Öğrenci Başarisina Etkileri (The Effect of Private Tutoring Centers on the Success of Students in the University Entrance Examinations), Hacettepe Üniversitesi Ĕgitim Fakültesi Dergisi ( Journal of the Hacettepe University School of Education), Vol. 21, pp. 89-96.

Organization for Economic Co-Operation and Development (OECD) (2011), Education at a Glance 2011: OECD Indicators, Paris: OECD Publishing.

http://dx.doi.org/10.1787/eag-2011-en

Accessed November 20, 2011

Ortaş, I. (2006) Eğitim Sistemimiz ve Öğrenci Secme Sınavı Sonucları (Our Education System and the Results of the Student Selection Examinations)

http://strateji.cukurova.edu.tr/EGITIM/pdf/ortas_ol.pdf Accessed February 15, 2012.

Özel Dersaneler Birliği (Öz-De-Bir) (2012) Web site, www.ozdebir.org.tr/default.aspx

Accessed February 29, 2012.

Student Selection and Placement Center (OSYM) (2012) web site, http://www.osym.gov.tr/belge/1-13244/kilavuzlar.html

Accessed February 29, 2012.

Tansel, A. and F. Bircan (2006) Demand for Education in Turkey: A Tobit Analysis of Private Tutoring Expenditures, Economics of Education Review, Vol. 25(3), pp. 303-313.

Tansel, A. and F. Bircan (2008) Private Supplementary Tutoring in Turkey: Recent Evidence on its Various Aspects. Bonn, Germany. Institute for the Study of Labor (IZA) Discussion Paper No: 3471. 
Turkish Accountants Association (2012) web site, www.muhasebetr.com/ulusalbasin/ Accessed February 15, 2012.

Turkish Educational Society (TED) (2005) Türkiye'de Üniversiteye Giriş Sistemi Araştırması ve Çözüm Önerileri (An Investigation of the University Entrance System in Turkey and Proposals for Solution) Ankara, Turkey: TED Publication.

Turkish Statistical Institute (TURKSTAT) (2011) web site, http://www.tuik.gov.tr/Start.do;jsessionid=6T13TySWcGny8ZrJPkG1JBKn70n72vZL6Q67p XXzRJdnqVcbTWbP!-1135667798

Accessed November 15, 2011.

Vatan Daily News-Paper (2009) Dersanelere \%25 Öğrenci Artışı Geliyor (25 percent More Students to the Private Tutoring Centers), 21 December, 2009.

World Bank (2011) Improving the Quality and Equity of Basic Education in Turkey: Challenges and Options, Washington DC: The World Bank Human Development Department, Europe and Central Asia Region. Report No: 54131-TR. 